\title{
Corporate Social Responsibility Scenario in Jordan: Transformation Context
}

\author{
Y. AL-DAAYA \\ PhD student, University of Debrecen Faculty of Economics and Business, albwairy@yahoo.com
}

\begin{abstract}
Corporate social responsibility (CSR) is not an alien concept in Jordan; although it has been seen so far as a philanthropic activity in keeping with Jordanian traditions. Jordan is an old state, politically stable and it is now in transformation from the point of CSR view, since more and more Jordanian stakeholders are becoming aware of the CSR concept and some firms in Jordan are working their way towards strategizing CR efforts. However, business still not fully grasps CSR practices and still considers CSR as part of philanthropy framework rather than lifting it to an upper level and taking it as a strategic approach to sustainability. Unfortunately, CSR in Jordan faces impeding obstacles: economic challenges, lack of government's incentives, skill-set, weak transparency and disclosure, and finally management and governance. This study attempts to present the picture of the transformation of CSR in Jordan and discuss its main steps of evolution, moreover, it aims to analyze the challenges and future prospects of CSR on a national level. Regarding the applied research method, the paper's data sources are of secondary research and I have used desk research to illustrate most important points and findings on the topic.
\end{abstract}

\section{Inroduction}

After 1990s of the last century Jordan has witnessed dramatic shift in business value system towards universal values, Due to the increasing wave of globalization and the influence of growing westernization; a tough transition process gave the private sector the driver seat as a leading player in innovation and creation of aNewsocio-economic - agenda. A new turn occurred shrinking the role of the state and ending decades of the crowding phenomenon between private and public sector, "the old paradigm that the state is the only entity responsible for the wellbeing and livelihood of the nation is becoming obsolete"[1].

In the era of globalization, CSR as new phenomenon was viewed by many Jordanians as an alternative legitimate tool needed to correct the state failure in the economic social agenda. Many questions arose in trying to describe the expected role of CSR in the country and its potential to make profound positive differences to Jordan and its social development, when the governments fail (CSR) must prevail.

The concept of CSR may be quite new to Jordan but it has a historical roots, it practiced as philanthropy or charitable work based on religious beliefs and powerful culture of giving, Loyalty and solidarity values which often override most other societal rules. According to Elian: 2005"In the MENA 
region CSR is not an alien concept; it has historical roots as the corporations which achieve extraordinary profit are not welcomed due to the religious beliefs that prohibit exploitation"[2].

There is much to build on, as Jordan now is looking into growing through the Growth of CSR."Her Majesty Queen Rania In her speech at the University of Jordan in 2008, which she has delivered upon receiving an honorary doctorate in Educational Sciences, her majesty has stressed that CSR is the responsibility of all Jordanians: Some of us may lose sight and find it difficult to focus and define where to start, or how to participate in influencing society. Others may believe that social responsibility is for others and overlook the fact that those participating do not take the place of those who are not. Building our future is a social responsibility that excludes nobody "[3].

While the country is now moving towards the right direction, to more comprehensive CSR approach, the concept of CSR is still waiting to become an important aspect of a sustainable business strategy and an integral part of core business activities.

This study is purely conceptual in nature. It aims to shed light on the evolution of corporate social responsibility in Jordan, and discuss the phases of its transformations also sought to identify the drivers that motivate companies to implement CSR programs as well as reviewing the challenges and the obstacles that restrict the adoption of such social initiatives.

\section{Corporate Social Responsiplity in Global Context}

The concept of CSR has evolved Globally and now encompasses range of associated and interchangeable terms and ideas, including corporate sustainability, corporate citizenship, responsible governance, triple bottom line, philanthropy, strategic philanthropy, shared value, Carroll (2008) highlights business philanthropy in the late nineteenth century as spearheading the development of the CSR concept, The principle which underpinned these activities was characterized mainly by religious groups [4].with the entry of the twenty-first century's businesses face intensified challenges, including rapid globalization, increasing environmental concerns and mounting pro-poor needs, there has been a growing need for the adoption of result-based CSR management and string evaluation of CSR performance [5]. "Her Majesty Queen Rania is a well-known advocate of CSR and very concerned on this issue in Jordan.. Her Majesty believes that CSR has moved from a trend to a way of doing business and then to criteria for success in the global economy" [3].

The role of corporations is currently undergoing an important transformation as stakeholders develop and modify their perceptions of the place and responsibilities of such organizations in society [6]."The way in which CSR is practiced and communicated is often related to specific cultural and social contexts, and in the Asia-Pacific region debates on CSR have tended to follow developments in the West [5].

The trend is certainly in effect in Jordan, (Elian 2004) in his paper which was presented at the (UJRC) experts meeting in Amman, stated that "Nowadays, the activities of CSR in many countries are getting importance and priority of transferring corporations into partners of development, where the royal vision of King Abdullah II, UNDP and other international organizations have called for" [2]. 


\section{Corporate Social Responsibility in Jordanian Context}

Literature revealed that the concept of CSR was new in Jordan, [7]. The recent study of The vision institute for civil studies in 2014 shows that's CSR in Jordan tends to be an ad hoc and to suffer from a lack of institutional mindset also continue to confuse between intermittent philanthropic acts and development projects that leave a sustainable impact on community"[8]. Also (Elian 2014) stated that "SCR in Jordan is a mixture of ethical voluntary actions and legally binding through political and legislation pressure" [11].

As some observers have pointed out, business organizations in Jordan still consider CSR as part of their corporate philanthropy framework with trend of voluntary, rather than taking it as a strategic approach to sustainability, besides that, they were unable to go beyond the framework of legal Compliance to various legal laws (Labor law, compensation act, environmental law, minimum wage act, etc.), Business firms in Jordan still make their profits , fulfill their tax duty, and then they donate a certain share of their profits to charitable causes.

In spite of that, No one denies that ,there are some national companies particularly The Jordanian companies who works internationally within the local Global Compact Group adopting corporate social responsibility in term of people, planet and profit and have clear and specified programs of CSR, Aramex, which is worldwide alliance form an extensive transportation network that spans the four corners of the globe would be an examples to talk about, particularly about its "Ruwwad" project which is a private founded non-profit organization in Jordan established in 2005,. Aims To support the young people to positively impact the processes of sustainable development. Also the Arab bank launched an initiative called together program which aims at involving people contribute to the community development. Furthermore Hikma Pharmaceuticals PLC, fastest growing multinational pharmaceutical group, received the 2012 Client Leadership Award presented by the IFC, a member of the World Bank Group. Sustainable development initiatives, quality standards in operations and excellence in corporate governance were key to receiving this award.

Over the course of 2014, a total of four hundred and forty four social activities was implemented by the business sectors in Jordan, where the banking sector was the most active sector in support CSR activities, [8] as shown in the table below.

\begin{tabular}{|c|c|c|c|c|c|c|c|c|}
\hline $\begin{array}{c}\text { Banking } \\
\& \\
\text { Insurance }\end{array}$ & Commerce & $\begin{array}{c}\text { Communications } \\
\text { And Information } \\
\text { Technology }\end{array}$ & Industry & Tourism & Education & Health & Transport & Construction \\
\hline 163 & 61 & 60 & 48 & 45 & 23 & 19 & 18 & 7 \\
\hline
\end{tabular}

Table 1. Number of CSR activities implemented by business sectors in Jordan In 2014.

(Source: Vision Institute for Civil Society Studies 2014)

CSR programs in Jordan targeted eight different social areas, namely: poverty alleviation and combating unemployment, sponsorship of activities, local community development, health and environment protection, national political affairs, sponsorship of sport events, art and culture, and support the company employees [8]. 
In the light of the widespread awareness of the CSR in Jordan, the government made a great efforts to stabilize the concept of CSR , for instance, inserting the concept in the strategic plan of the ministry of social development for years 2001-2009 and in 2007 established the guide of CSR, issued by the ministry of justice, in addition, A number of CSR and sustainability forums across the country were lunched, such as : in 2009, The National Forum for Social Responsibility was launched by the Al Urdun Al Jaded Research Centre (UJRC), aiming to coordinate CSR in Jordan ,in 2012the business Development Center in Jordan (BDC), launched the "CSR in action Jordan, an initiative that aims to develop and enhance the practices and awareness of CSR activities among students In Jordan. While there is a shift appeared primarily in the perception of CSR, still there is a great need to build more awareness on CSR in Jordan.

\subsection{The Driving Forces behind the Implementation of CSR in Jordan}

Porter and Kramer (2011) present four motives for business to integrate the CSR concept into their core business: moral obligation, sustainability, license to operate and reputation and even raising the value of its stock [9] also, The study of Ararat Melsa (2004) CSR in the Framework of Government Development of Business System concluded that :economic dimension, the role of the state, the legal requirement, the cultural characteristics of the society are endogenous drivers for corporate social responsibility behavior of the corporations in a country while the international organizations and donor may be considered as exogenous driving forces behind the activities of corporate social responsibility [10].

In the Jordanian context, a recent study of Elian (2014) which is based on a purposive sample of large companies out of 190 public shareholding companies registered at the Amman Stock Markets shows that CSR driving forces in Jordan included, in descending order; cultural ethics, company by law, customary rules, country law, Instructions by Associations political pressure, competitors, and NGO pressure, No companies consider customer pressure as a driving force [11]. as well as study conducting by the vision institute for civil society in 2014 on 270 companies spread over a score of eleven economic sectors to identify the drivers that motivate companies to implement social responsibility programs in Jordan it shows that the most of the companies $81 \%$ practice this out of an ethical commitment by the corporate management, other CSR driving forces included in descending order: Ethical commitment, Sympathy toward vulnerable group ,Religious conviction, Addressing societal dilemma, Marketing strategy ,Responding to NGO,s appeals Strengthen public relation, complying with Corporate governance \& citizenship, Addressing political concern [8].

The CSR agenda in Jordan has been moved forward due to the pressure from external factors through the foreign multinational companies working in the country as part of the globalization phenomena, According to the (IMF 2005) report, the top trade policies for Jordan in1996 was" Integrate Jordan into the global economy, increase domestic competition, and create conditions for export-led growth [12]. Ararat (2006) study revealed that CSR in Jordan is generally driven by increased international and local competition due to liberalization; concerns for efficiency and productivity. Also from the International business relations; learning by examples [13]. Also The Study of Hussein Al-Asraj (2010) 
"Corporate Social Responsibility" Arab Planning Institute, Kuwait, February, concluded that the role of CSR in different countries has accelerated due to the reduction of government services to the public after the privatization of public enterprises [14]. The proactive role of the government has been witnessed considering the CSR as an economic concept, Ararat (2006)" results suggest that Jordanian laws, as drivers to CSR in Jordan, may be the reason behind socially responsible acts by these companies [13].

\subsection{Evolution of Corporate Social Responsibility Jordan}

Jordan is an old state, with religiously inspired culture of giving(Islam recommends social cooperation), where the Muslim majority of the populations, and has been remained stable for decades with developed legal structure, despite numerous conflicts in neighboring countries [15]; therefore, the trend of behavior toward the CSR concept can be expected; now a days The trend is clearly visible in Jordan as more and more business organizations have started paying more attention to their social responsibility.

The concept of CSR has been changed over time in Jordan and developed since the beginning of the state in 1921, to describe the evolution of the CSR concept; we divided the transformation process into two phases Based on country's political and economic background however, it's not static, and characestic of one phase can also be appeared in the other.

\begin{tabular}{|c|c|c|}
\hline PHASE & CSR APPROACH & " KEY STRATEGY \\
\hline $\begin{array}{r}\text { Phase I TILL } 1999 \\
\text { The crowding } \\
\text { phenomenon } \\
\text { between private and } \\
\text { public sector }\end{array}$ & $\begin{array}{l}\text { Charity and } \\
\text { philanthropy }\end{array}$ & $\begin{array}{l}\text { Non state - random initiatives for public } \\
\text { good, motivated by culture and religion }\end{array}$ \\
\hline $\begin{array}{r}\text { Phase II 2000- } \\
\text { present } \\
\text { New socio- } \\
\text { economic - } \\
\text { political agenda }\end{array}$ & $\begin{array}{c}\text { Smart } \\
\text { philanthropy: } \\
\text { Semi-strategic } \\
\text { approach }\end{array}$ & $\begin{array}{r}\text { Nonrandom actions with the adoption } \\
\text { of some aspect of the CSR agenda, } \\
\text { motivated by Globalization } \\
\text { Liberalization the economy } \\
\text { Political Pressure, New Country laws, } \\
\text { NGO pressure, Market competition, } \\
\text { Cultural Ethics }\end{array}$ \\
\hline
\end{tabular}

Table 2. Phases of CSR practices of Jordan

(Source: Authors survey of literature in CSR)

\subsubsection{Phase I.}

Since the establishment of Emirate of Transjordan in 1921 the former name of the Hashemite king dome of Jordan, and during decades of the crowding phenomena between the public and the private sector,CSR was understood as a philanthropic work, a non-institutionalized phenomenon based on traditions presented by the Arab norms, and religious beliefs, Islam recommends social co-operation. while, the private sector was mainly small, and consisted of family businesses owners, it has been 
asked to give back to society as part of their religious practice and not as part of their responsibility toward society where, "the profit imperative is tempered by religious belief and ethical values"[2] also according to al-maghribi (1996) CSR is obligatory on each Muslim community to implement it in society in any field [16]. Later on, and before ending of the last century the majority of companies in Jordan is still unaware of the concept of CSR and still considers CSR as part of their corporate philanthropy without having clear philosophy towards social responsibility issues, for example, The Islamic Jordan Bank helps in funding programs for group weddings, The Jordan Kuwait Bank has designed signs for large public bus stops- and spreading them in the streets of Amman according to AlDmour (2011) The study of Elaian (1994) which aimed at examining to what extent social responsibility was adopted by Jordanian companies, and how that might affect the performance of these companies. found that the Public Shareholding Companies (PSC) took part in social responsibility through community engagement practices and incentives offered to their employees, without having clear philosophy towards social responsibility issues. [3]

Due to macroeconomic imbalances, in 1989 Jordan has started new socio-economic -political agenda ,A new wave of pro -market policies started with the liberalization reforms upon IMF adjustment program and through a series of privatization initiatives downsized the public shares in the productive sectors and applied more legalistic approaches with new legal and public regulation of business activities. [17] according to the IMF2005 report, the plan which was adopted till 1997"Liberalize the economy and its institutions, eliminate distortions, and develop an appropriate business climate Reduce government direct involvement in production, and enhance the role of the private sector. Make room for active participation of the private sector in investment in infrastructure and basic services" [12]. At the same time the state lunched the Charter of Civil Liberties called (Mithaq) helped to create a favorable environment for civil society organizations.

Till the beginning of the 21st century and even while the transformation process of the political socieconomic agenda which took a place at the last decade of 20the century the state was the major economic player assumed responsibility for social and economic development with tendency to empower the private sector, however, through that period, the philanthropic pattern was the title for the CSRagenda practiced in Jordan.

\subsubsection{Phase II.}

In February 1999 Al-Hussain, king of Jordan dies, King Abdullah II enthroned, and the government introduces plan for social and economic transformation, and has committed itself to establishing a modern market economy with a human touch. In July 2004 Jordan finished the last agreed upon IMF adjustment program, according to the IMF 2005report the plan which was followed from 1999 till 2003"establish a conducive investment climate for the private sector (domestic and foreign), Accelerate privatization, Public sector disengagement from direct economic activities to take on the more regulatory role. Reduce government's role in direct production; make room for more a more dynamic private sector. [12]. Also In 2005, Jordan adopted a comprehensive National Agenda for the next [10] years that reflects the vision of the New leadership, His Majesty King Abdullah II of a modern civil society, includes Political development with increasing participation at all levels in the decision 
making process, and address other social, economic issues [17].furthermore Jordan signed several economic and trade cooperation agreements with countries all over the world. Such as: in 1999 joined the World Trade Organization (WTO) and the agreement comes into effect in2002, in 2000 Jordan and United States have signed Jordan-US Free Trade Agreement. On the other hand, The Jordanian Education Initiative (JEI) was launched in 2003 at the World Economic Forum meeting "The goal of this initiative was to achieve educational reform in order to develop a knowledge economy, stimulate economic growth and provide future employment opportunities" [15].

At the beginning of the 21st century, While the role of the private sector is becoming more and more evident, Jordan has witnessed its first true movement toward CSR perception, a shift toward more comprehensive approach of CSR driven by: better respect for civil rights, more competitive market, and with developed legal system, and by robust FDI and strong public-private investment through the privatization of formerly government-owned businesses, intensified interaction with international market, Most important the foundation of a number of local CSR specialized organizations and the conclusion of a number of CSR and sustainability forums across the country.

In the scenario of the second phase, with the new global businesses culture, CSR concept have moved from philanthropy, toward semi- strategic philanthropy or a smart philanthropy: which is" about how businesses can manage the impact of charitable contributions to support the business's strategy, while supporting the national development agenda" [18], its making philanthropy more strategic by adopting some aspects of CSR global agenda, examples on this approach: financial literacy initiatives lunched by the banking sector and the Risk awareness campaigns adopted by the insurance sector.

\subsection{Challenges}

In the rest of this paper, we would summarize the key hurdles facing CSR in Jordan as follows: The economic challenge: The economic situation has a tremendous effect on business activities, it's true that in in times of recessions business must prioritize.," the current economic situation in Jordan grappled with addressing a number of exogenous shocks, notably the closure of land trade routes with Syria and Iraq, and other security-related challenges which adversely impacted the economy" [19]. Pushing CSR to be less important consideration which is often reflected in a company's budget -cuts on social projects, a recent study by vision institute 2014 shows that the fluctuations in companies profit came at the top of the challenges which impedes the ability of devising CSRplans in addition to the low budget provision.

Lack of Government's incentives: the government should motivate the private sector to adopt better CSR practices. Through grants exemptions and offer an incentive scheme to companies which shows the highest level of social responsibility. As well as by recognition according to U.S.AID study corporate responsibility \& public, private partnership'2010: "recognition was mentioned by most companies, whether it is a public recognition or by the royal figure" [20].

Skill-set: possessing the right skill-set to implement CSR, many organizations may have the will to implement CSR, but do not possess the right skill-set to do so, or are not aware of what kind of skills they need in order to manage successful CSR initiatives. 
Governance: lack of monitoring and evaluation process of CSR projects, companies do not track their CSR activities, therefore many projects are unsuccessful and/or not sustainable.

Weak transparency and disclosure: according to a survey conducted in 2014 by vision institute of civil society studies targeted 270 companies in Jordan, it shows that more than $55 \%$ of the targeted companies do not provide, disclose of their sea activities. [8] Transparency, disclosure and reporting of information on CSR activities of Jordanian companies are still not widely disseminated [11].

\section{Conclusion}

The CSR concept has evolved over time in Jordan, in its early stages it was treated as charity and philanthropy work with direct influence from culture, religion, and family values, since the early 2000s, the concept has witnessed its true movement toward more comprehensive approach, anew shift in the perception of CSR called smart philanthropy, which makes the philanthropy more stratgigic through adopting some aspects of global agenda, however, today a confused picture of CSR is seen between the philanthropic act as a responsiplity to give something to society and business initiatives that leave a direct sustainable impact at the development end.

Despite the growing tendency for positive attitude towards CSR in Jordan, it's still suffering from a lack of value-creation and considered as a way to create publicity, enhance the reputation of a company and strengthen its brand, through public relation and marketing campaigns, in recent studies. (Elian 2014) stated that" Maintaining good image in the eyes of the shareholder, employees, customers and the government, is the greatest motivation for practicing CRS activities" [11].

The challenges facing CSR Jordan are: The economic situation, Lack of Government's incentives, Weak transparency \& disclosure, Governance.

The most driving forces behind adopting CSR practices in Jordan are: religious beliefs and Ethics of the society, the standing laws and regulation imposed by the government, also the competitive market and the multinational investment within the globalization phenomena as an exogenous factor.

The private sector is expected to be mature enough to file a divorce between marketing or public relation and the CSR practices as well as it needs to broader its sense of responsibility toward the community and integrate CSR into their vision and philosophy where the philanthropy falls short of encompassing.

\section{References}

[1] Odeh Al-Jayyousi, 2011Corporate Social Responsibility: Transforming the Jordanian's Corporations, corporate governess and responsibility, realizing sustainability forum, 2011

[2] Khalil Elian2004, Corporate Social Responsibility (CSR) A Theoretical Background, paper was presented at the (UJRC) experts meeting in Amman, June 29 the 2004 
[3] Hani H. Al-Dmour and Hayat A. Askar2011, The Impact of Corporate Social Responsibility on Companies Perceived Performance: A Comparative Study between Local and Foreign Companies in Jordan, Journal of Business Administration, Volume 7, No. 1, 2011

[4] Carroll, A.B (2008). A history of corporate social responsibility: concepts and practices. In The Oxford Handbook of Corporate Social Responsibility, C. Andrew and others, Eds. Oxford: Oxford University Press. pp. 19-46.

[5] Economic and Social Commission for Asia and the Pacific (2009). Creating Business and Social Value: The Asian Way to Integrate CSR into Business Strategies. Sales No. E.10.II.F.18. Available from http://www.unescap.org/tid/publication/indpub2565.asp.

[6] Brønn, P.S., \& Brønn, C. (2003). A reflective stakeholder approach: Co-orientation as a basis for disclosure and learning. Journal of Disclosure Management, 7(4), 291-303.

[7] Elian, K. 2005. The State of Corporate Social Responsibility in Jordan: Case Studies from Major Business Sectors, Amman, Jordan: Al-Urdun Aljadid Research Center (UJRC).

[8] Vision institute for civil society studies 2014, corporate social responsiplity in Jordan current status and future prospects, survey analysis of Jordan CEO perception of CSR, 2 2014, vision institute for civil society studies, Amman

[9] Porter, M., and M.R. Kramer, 2011creating shared value: how to reinvent capitalism - and unleash a wave of innovation and growth. Harvard Business Review, January- February 2011

[10] Ararat Melsa 2004, Corporate Social Responsibility in the Framework of Government Development of Business System. Istanbul.

[11] Khalil Elian Abdel Rahim, 2014, Role of Corporate Social Responsibility in alleviating poverty in Jordan: international Journal of Business and Social Research, 2014, vol. 4, issue 3, March 2014

[12] International MonetaryFundIndependent Evaluation Office, Evaluation Report IMF Support to Jordan, 1989-2004 December 6, 2005

[13] Ararat, M. 2006. Corporate Social Responsibility across Middle East and North Africa, Faculty of Management, Sabanci University, Draft available at SSRN: http://ssrn.com/abstract=1015925

[14] Alasraj, Hussein (2010) Corporate Social Responsibility .Arab Planning Institute. Kuwait

[15] Aaron Batsakis .Salik Farooq, Joanna Kopicka Ko Nishiuchi ,Adam Van Loon ,2008 Private Sector Development in Jordan: Harnessing technology to Boost Development ,The University of Michigan March 2008 P2

[16] Almaghribi, abd al-Hamid, abd al-Fattah. (1996) Almas'uliyyah al-Itima'yyah li al-bunuk alIslamiyah .alqahira:alma'had al-alami li alfikri al-islami 
[17] Jaradat,Hamza ADAT,2010,Jordan's Economy Crisis, Challenges \& Measures ,Paper Work presented at 3rd Annual Meeting of Middle East and North African Senior Budget Officials (MENA-SBO) Dubai, UAE Oct. 31-Nov. 1, 2010

[18] Jordan's responsible competitiveness report 2009, Strategies for the banking, insurance and meat processing sectors, Available to download from www.responsiblecompetitiveness.org

[19] Central bank of Jordan, annual report 2015. Summary of economic development in 2015 amman.jordan

[20] United States Agency Report, 2010.Public Action for Water, Energy and Environment Project." "Final Report on Survey Findings of NGOs and CBOs - Efforts on Social Marketing, Outreach and Communication" no. 6, March 2010 